\title{
ANATOMÍA CUANTITATIVA COMPARADA DE ALGUNAS ESPECIES DE GRAMÍNEAS DE LA PROVINCIA DE SANTA FE
}

\author{
Heinzen, F. ${ }^{1}$, Ramos, J. $^{1}$ \& Tivano, J. C. ${ }^{1}$
}

\section{RESUMEN}

Las Gramíneas forrajeras presentan diferentes vías de fijación del $\mathrm{CO}_{2}$, las que están acompañadas por diferencias anatómicas, ultraestructurales y bioquímicas, que condicionan el consumo y la digestión por parte del animal. La proporción relativa de los distintos tejidos foliares (anatomía cuantitativa) está directamente relacionada con la digestibilidad y, consecuentemente, con la calidad forrajera de la especie.

El objetivo de este trabajo es estudiar la proporción relativa de los distintos tejidos foliares en especies de Gramíneas que integran los pastizales naturales de la Provincia de Santa Fe. Se trabajó con Setaria cordobensis R.A.W. Herm., S. fiebrigi R.A.W. Herm., Urochloa lorentziana (Mez) Morrone \& Zuloaga, Pappophorum caespitosum R.E. Fr., P. vaginatum Buckely, Sorghastrum pellitum (Hack.) Parodi , Sporobolus indicus (L.) R. Br., Paspalum plicatulum Michx.,Nassella neesiana (Trin. \& Rupr.) Barkworth y Luziola peruviana Gmelin.

Para los estudios anatómicos cuantitativos muestras de la parte media de la lámina de la hoja bandera fueron fijadas en FAA, cortadas con micrótomo rotativo y coloreadas con safranina-fast green. Los transcortes observados con un microscopio óptico se dibujaron, determinándose el área de cada tejido con un planímetro digital electrónico PLANIX 7 y el número de haces vasculares en la semilámina. Se determinó el TLND (total de tejidos lentamente digestibles e indigestibles: xilema + epidermis + vaina del haz + esclerénquima) para inferir su calidad forrajera. Se presentan y discuten los porcentajes de los distintos tejidos foliares, el TLND y el número de haces vasculares de las especies estudiadas.

Palabras clave: Gramíneas, valor nutritivo, anatomía foliar, lignina.

1.- Morfología Vegetal. Facultad de Ciencias Agrarias, Universidad Nacional del Litoral. Kreder 2805. (3080) Esperanza, provincia de Santa Fe. Telefax: (03496) 426400.

E-mail: jramos@fca.unl.edu.ar

Manuscrito recibido el 13 de mayo de 2002 y aceptado para su publicación el 4 de diciembre de 2002. 


\section{SUMMARY}

\section{Comparative quantitative anatomy of grass species in Santa Fe province}

Forage grasses present different $\mathrm{CO}_{2}$ fixation pathways, which showed anatomic, ultra-structural and biochemical differences affecting both animal consumption and digestion. Relative ratio of diverse foliar tissues (quantitative anatomy) is directly linked to digestibility and, therefore, to forage quality. The objective of the present work is to assess the relative ratio of different foliar tissues in grass species found in Santa Fe province rangelands. The study was carried out on Setaria cordobensis R.A.W. Herm., S. fiebrigi R.A.W. Herm., Urochloa lorentziana (Mez) Morrone \& Zuloaga, Pappophorum caespitosum R.E. Fr., P. vaginatum Buckely, Sorghastrum pellitum (Hack.) Parodi , Sporobolus indicus (L.) R. Br., Paspalum plicatulum Michx., Nassella neesiana (Trin. \& Rupr.) Barkworth y Luziola peruviana Gmelin.

Samples from medial portion of flag leaf blade were fixed in FAA, sectioned with a rotative microtome and stained with safranine-fast green, in order to perform the quantitative anatomic studies. A PLANIX 7 electronic digital planimeter was utilized to determine proportion corresponding to each tissue from transverse section drawings. The latter were observed under an optic microscope. Number of vascular bundles in the half-lamina was also determined. Total slow and non digestible tissues (TSND), i.e. xylem + epidermis + bundle sheath + sclerenchyma were determined, in order to assess forage quality on different studied taxa. Percentages of diverse foliar tissues, TSND and number of vascular bundles in the different species are presented and discussed.

Key words: Gramineae, nutritive value, leaf anatomy, lignin. 